\title{
Actin Expression in Smooth Muscle Cells of Rat Aortic Intimal Thickening, Human Atheromatous Plaque, and Cultured Rat Aortic Media
}

\author{
Giulio Gabbiani, Oliver Kocher, and William S. Bloom \\ Department of Pathology, University of Geneva, \\ CH 1211 Geneva 4, Switzerland \\ Joel Vandekerckhove \\ Laboratory of Histology and Genetics, Ledeganckstraat 35, \\ B-9000 Gent, Belgium \\ Klaus Weber \\ Max-Planck Institute for Biophysical Chemistry, \\ D-3400 Goettingen, Federal Republic of Germany
}

bstract. Actin of smooth muscle cells of rat and human aortic media shows a predominance of the $\alpha$-isoform. In experimental rat aortic intimal thickening, in human atheromatous plaque, and in cultured aortic smooth muscle cells, there is a typical switch in actin expression with a predominance of the $\beta$-form and a noticeable amount of $\gamma$-form. This pattern of actin expression represents a new reliable protein-chemical marker of experimental and human atheromatous smooth muscle cells.

\section{Introduction}

Although it is generally accepted that smooth muscle cells proliferation and migration from the arterial media into the intima are the essential steps in the development of the atheromatous plaque, the causes underlying these phenomena are still controversial (for review see references 1-4). Moreover, despite the large amount of work performed in several laboratories, little is known about morphological and/or biochemical differences between medial smooth muscle cells and the smooth muscle cells of the atheromatous plaque $(2,4,5)$. We report that in smooth muscle cells of human atheromatous plaque and rat

Dr. J. Vandekerckhove is a Research Associate of the Belgian National Fund for Scientific Research (N.F.W.O).

Received for publication 6 June 1983 and in revised form 26 September 1983.

J. Clin. Invest.

(C) The American Society for Clinical Investigation, Inc.

$0021-9738 / 84 / 01 / 0148 / 05 \quad \$ 1.00$

Volume 73, January 1984, 148-152 aortic intimal thickening produced by removal of the endothelium (6) (the most commonly used model for the atheromatous plaque), as well as in primary cultures of smooth muscle cells from rat aortic media, there is a switch in actin expression when compared with smooth muscle cells of normal media. This switch involves the ratio of the different actin isotypes previously shown to be genetically regulated and to change upon differentiation $(7,8)$. It may be useful in defining the phenotypic features of atheromatous smooth muscle cells and in studying the development of such features in experimental animals and humans.

\section{Methods}

Endothelial removal was performed on 15 male Wistar rats (250-300 $\mathrm{g}$ body $\mathrm{wt}$ ) essentially according to Baumgartner and Studer $(6,9)$. An embolectomy catheter (2F Fogarty, Edwards Laboratories, Santa Anna, CA) with a deflated rubber balloon at the distal end was introduced into the left carotid artery up to the diaphragmatic portion of the aorta. The balloon was inflated with $0.05 \mathrm{ml}$ of water and withdrawn slowly. This procedure was repeated once and the completeness of aortic denudation was verified in four additional animals by intravenous injection of Evan's blue ( $1 \mathrm{ml}$ of $1 \%$ solution in $0.9 \% \mathrm{NaCl}$ ) immediately after ballooning. The animals were killed $20 \mathrm{~min}$ later by perfusing through the left ventricle of the heart $0.9 \% \mathrm{NaCl}$. The isolated opened aortas appeared under a magnifying glass completely blue. Five untreated rats were used to collect normal media. $2 \mathrm{wk}$ after endothelial removal rats were intravenously injected with Evan's blue to visualize the areas free of endothelium (blue areas) compared with areas that had reendothelialized (white areas). After $20 \mathrm{~min}$, rats were killed and the endothelial thickening in the blue areas was dissected from the remaining media under a magnifying glass. Completeness of dissection and the morphology of media and intimal thickening were monitored by light and electron microscopy as previously described (9).

Normal arterial tissue and atheromatous plaques were collected at autopsy from the thoracic aorta of 14 individuals (8 males and 6 females) with age ranging from 8 to $81 \mathrm{yr}$ (mean $53.6 \mathrm{yr}$ ). All autopsies were 
performed within $<10 \mathrm{~h}$ after death. Only macroscopically typical fibrous or fibrolipidic plaques were dissected under a magnifying glass. Normal intima was gently scraped and the media was dissected from the same cases. Specimens macroscopically similar and adjacent to those used for biochemical analysis were examined by light and electron microscopy as previously described (9).

Smooth muscle cells from the rat thoracic aorta were cultured after enzymatic dispersion (10-12) and kept in supplemented Dulbecco'smodified Eagle's medium containing one of the three: $10 \%$ plasmaderived serum (13) (PDS), ${ }^{1} 0.5 \%$ fetal calf serum (FCS) or $10 \%$ FCS the cells were kept in culture for 8-13 $d$ and then analyzed for actin content and isoforms.

Total tissues were dissolved directly in sample buffer containing 1 $\mathrm{mM}$ phenylmethylsulfonyl fluoride, sonicated (three times $5 \mathrm{~s}$ at setting 7 of a Branson sonifier, Branson Sonic Power Co., Danbury, CT), boiled for $3 \mathrm{~min}$ (14), and analyzed by one-dimensional sodium dodecyl sulfatepolyacrylamide gel electrophoresis (15). Quantification was made by means of planimetry using a Chromoscan MKII (Joyce Loebl, Düsseldorf, FRG) as previously described (14). Protein determination was according to Bradford (16). Actin isoforms were characterized either by two-dimensional gel electrophoresis according to O'Farrel (17) with minor modifications (18) and/or by the characteristic migration pattern of their isolated ${ }^{14} \mathrm{C}$-labeled $\mathrm{NH}_{2}$-terminal tryptic peptides in the two-dimensional paper electrophoretic system described (for technical details see reference 19).

\section{Results}

The morphology of normal rat intima and media, and of intimal thickening was as previously described (9). In particular, intimal thickening of blue areas contained virtually only smooth muscle cells. Normal human intima contained a layer of endothelial cells and several subendothelial cells in a thin layer of connective tissue. The normal media contained only smooth muscle cells as well as collagen and elastin. The atheromatous plaques contained mainly modified smooth muscle cells showing lipid accumulation (such modified smooth muscle cells represented $80 \%$ of cellular elements as judged by examining at least 10 randomly taken electron micrographs for each specimen), but also foam and mononuclear cells (20). Lipids were present extracellularly in variable amounts according to the case and to the plaque (21).

Total actin content of samples from normal rat media, intimal thickening and media under the thickening was found to be similar $(12.60 \pm 0.6,11.64 \pm 0.5$, and $12.46 \pm 0.5 \%$ of total proteins, respectively). In contrast, these samples differed significantly in the ratio of the different isoactins. While normal media contained mainly the $\alpha$-smooth muscle form and in addition the $\beta$-cytoplasmic form, intimal thickening was significantly enriched in cytoplasmic actins. It revealed not only a predominance of the $\beta$-form but also a noticeably greater amount of the $\gamma$-form whereas the $\alpha$-form was strongly reduced (Fig. 1). Quantitative data were obtained by measuring the radioactivity present in each of the spots (Fig. $2 A, 2 B$, and Table I), taking

1. Abbreviations used in this paper: FCS, fetal calf serum; PDS, plasmaderived serum.
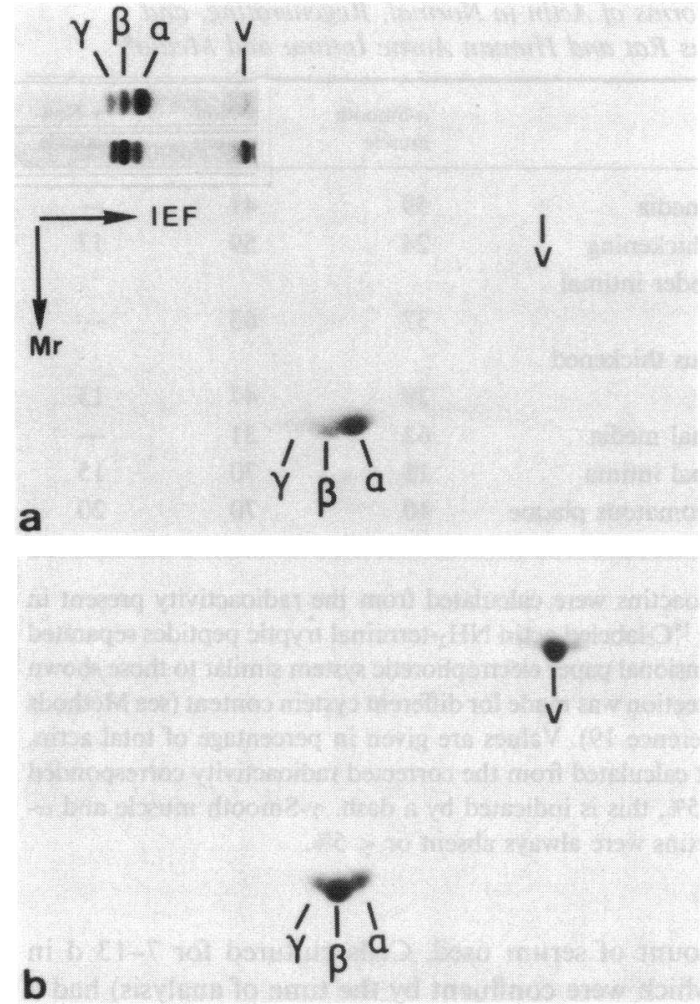

Figure 1. Actin isoforms in normal and injured rat aortic media. Two-dimensional gels of total extracts of normal rat media $(a)$ and isolated intimal thickening $(b)$; gels were loaded with the same amount of protein in order to separate the spots of different actins. The major actin spot is $\alpha$-actin in normal smooth muscle cells and $\beta$-actin in regenerating smooth muscle cells. Note also the increase in $\gamma$-actin in regenerating cells. Note that in $(b)$ the vimentin spot $(V)$ is more pronounced than in $(a)$. The insert shows one-dimensional isoelectric focusing gels of the same preparations. They provide a clear distinction between the different actin types present.

into account that smooth muscle actin-derived $\mathrm{NH}_{2}$-terminal peptides display two labeled cystein residues, whereas striated muscle and cytoplasmic actin peptides contain only one labeled residue (for documentation see references 7 and 19). Similar observations were made when actin isoforms of normal human intima and media were compared with the isoforms present in the atheromatous plaques (Fig. $2 C$ and $D$ ). Normal media contains the $\alpha$-smooth muscle isoform as the major component; $\alpha$-smooth muscle and $\beta$-cytoplasmic actin are present in a 2:1 ratio. In contrast, atheromatous plaques display the cytoplasmic actins $\beta$ and $\gamma$ in a 7:2 ratio, while the amount of $\alpha$-smooth muscle actin is strongly reduced and accounts only for some $10 \%$ of the total actin (Table I).

Cultured rat aortic smooth muscle cells showed clear differences in their content of actin isoforms (judged by isoelectric focusing and bidimensional gels) according to the time of culture 
Table I. Isoforms of Actin in Normal, Regenerating, and Atheromatous Rat and Human Aortic Intima and Media*

\begin{tabular}{llll}
\hline & $\begin{array}{l}\alpha \text {-Smooth } \\
\text { muscle }\end{array}$ & $\begin{array}{l}\beta \text {-Non- } \\
\text { muscle }\end{array}$ & $\begin{array}{l}\gamma \text {-Non- } \\
\text { muscle }\end{array}$ \\
\hline $\begin{array}{l}\text { Rat normal media } \\
\text { Rat intimal thickening }\end{array}$ & 59 & 41 & - \\
$\begin{array}{l}\text { Rat media under intimal } \\
\quad \text { thickening }\end{array}$ & 24 & 59 & 17 \\
$\begin{array}{l}\text { Rat media plus thickened } \\
\quad \text { intima }\end{array}$ & 37 & 63 & - \\
$\begin{array}{l}\text { Human normal media } \\
\text { Human normal intima }\end{array}$ & 29 & 47 & 13 \\
Human atheromatous plaque & 15 & 31 & - \\
& 10 & 70 & 15 \\
\hline
\end{tabular}

* Ratios of isoactins were calculated from the radioactivity present in the respective ${ }^{14} \mathrm{C}$-labeled actin $\mathrm{NH}_{2}$-terminal tryptic peptides separated in a two-dimensional paper electrophoretic system similar to those shown in Fig. 2. Correction was made for different cystein content (see Methods section in reference 19). Values are given in percentage of total actin. If the amount calculated from the corrected radioactivity corresponded to a value $<5 \%$, this is indicated by a dash. $\gamma$-Smooth muscle and $\alpha$ sarcomeric actins were always absent or $<5 \%$.

and the amount of serum used. Cells cultured for 7-13 $\mathrm{d}$ in $10 \%$ FCS (which were confluent by the time of analysis) had a pattern (Fig. 3) superimposable to that of intimal thickening or of atheromatous plaque, i.e., a decrease of $\alpha$-isoform, a predominance of $\beta$-isoform, and a relative increase of the $\gamma$-isoform, whereas cells freshly isolated from the media (Fig. 3) and cells cultured for $7-13 \mathrm{~d}$ in PDS or $0.5 \%$ FCS (which practically showed no replication) had a pattern of actin isoforms similar to that of normal rat media.

\section{Discussion}

Actin and other fibrous proteins account for a large proportion of the cellular cytoplasm. These cytoskeletal elements are present in histologically different cell types as distinct members of various multigene families $(8,22-24)$. The characterization of cytoskeletal elements in a given cell or tissue has been shown to represent a reliable tool for the study of differentiation phenomena, and for the identification of the origin of various tumors (for review see references 23, 25, 26). Moreover, the evaluation of quantitative and qualitative changes in the organization of cytoskeletal elements appears more and more useful as marker of the degree of cellular adaptation during various pathological phenomena (25). Actin is quantitatively the most important cytoskeletal protein and is expressed probably in all eukariotic cell types. Although very conserved throughout the phylogenetic tree, actins from different tissues are heterogeneous $(7,8)$. This heterogeneity is shown by isoelectric focusing and more precisely by the chemical analysis of the amino-terminal peptides of the different isoforms (19).
Our results show that compared with normal aortic media, intimal thickening of rat aorta after endothelial injury, rat aortic cultured cells, and human atheromatous plaque develop a switch in actin isoform expression from a predominance of the $\alpha$-type to a predominance of the $\beta$-type with an increase of the $\gamma$-type. The change of isoactin expression in human atheromatous plaque might have been amplified by the presence of contaminating nonmuscle cells (Results), however, since most (80\% according to our morphological criteria) of the cells in the plaques examined are smooth muscle cells (1-5), it can be concluded that the decrease of the $\alpha$-smooth muscle variant is mainly due to a change in the ratio of the isoactins present in the plaque smooth muscle cells, i.e., cytoplasmic actins are overproduced in the plaque. Moreover, similar changes are present in pure preparations of newly growing smooth muscle cells such as rat intimal thickening after endothelial injury and primary cultures of rat aortic media.

Smooth muscle cells of human or animal (both spontaneous and experimental) atheromatous plaques, differ morphologically from normal medial smooth muscle cells in that they contain a more developed rough endoplasmic reticulum and Golgi apparatus and a less developed microfilamentous apparatus $(3,9$, 27,28 ), which makes them similar to myofibroblasts of granulation tissue $(9,25)$. The finding of a molecular switch in actin

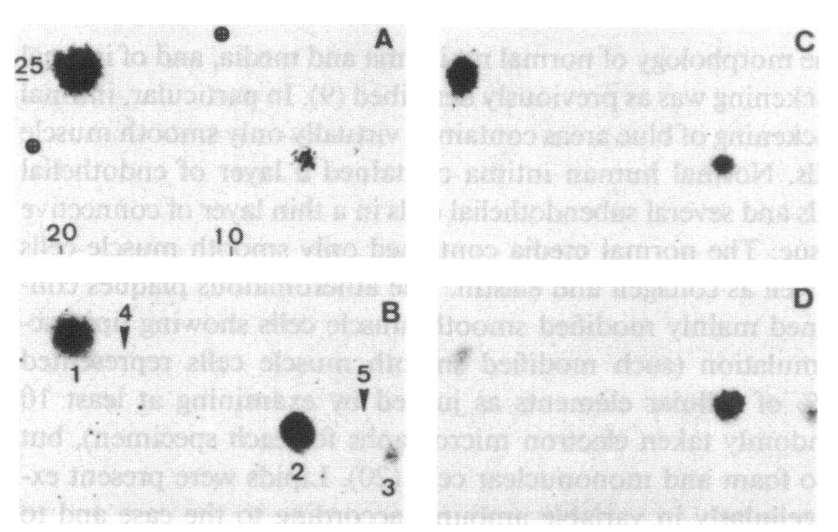

Figure 2. Two-dimensional separation pattern of the amino-terminal tryptic peptides of actin isoforms in normal and pathologic rat and human aortae. Protein samples were reduced and alkylated at cystein residues using $\left[{ }^{14} \mathrm{C}\right]$ iodoacetate. Total protein was recovered, digested with trypsin, and subjected to the fingerprinting system described (19). Horizontal separation is by electrophoresis at pH 3.3, separation in the vertical direction is at $\mathrm{pH}$ 6.5. The migration distance from the origin is indicated (in centimeters) on the edges of $A$. The anodic $(+)$ side for each electrophoretic direction is given in $A$ (for details see reference 19 ). Spots 1,2 , and $3(B)$ represent peptides derived from vascular smooth muscle actin, $\beta$-cytoplasmic actin, and $\gamma$ cytoplasmic actin, respectively. Arrows numbered 4 and 5 point to the positions of the peptides of $\gamma$-smooth muscle actin and striated muscle $\alpha$-actin. The latter isoactins are absent or only present in $<5 \%$ of the total actin content. $A$ : rat normal media; $B$ : rat intimal thickening; $C$ : human normal media; $D$ : human atheromatous plaques. 


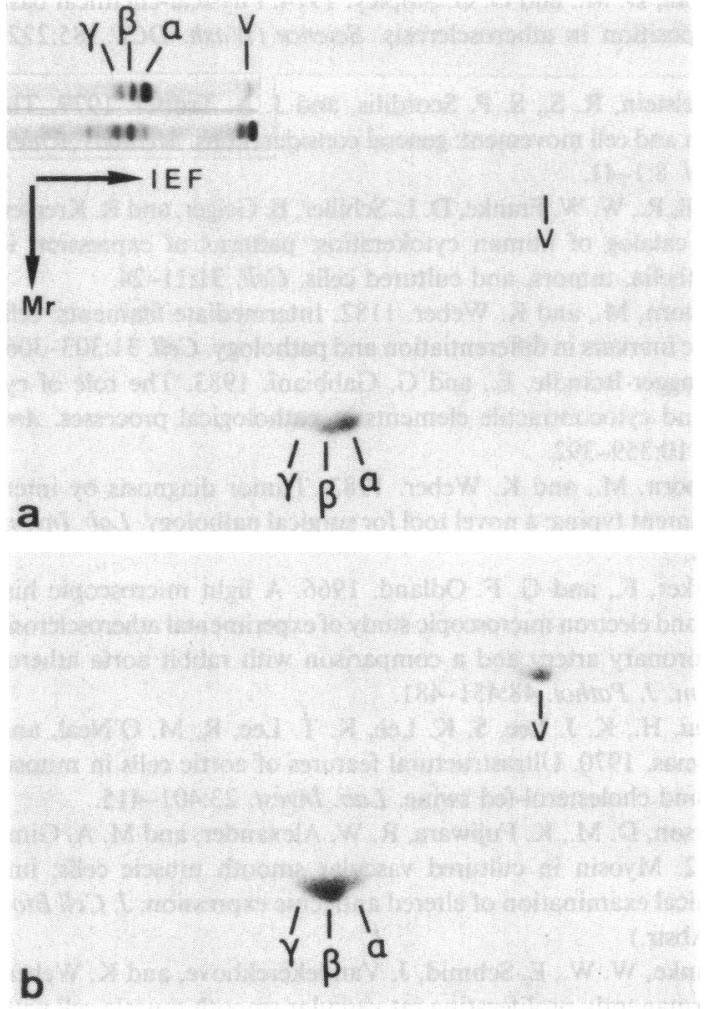

Figure 3. Actin isoforms in freshly isolated and cultured confluent rat aortic smooth muscle cells. Two-dimensional gels of freshly isolated rat aortic smooth muscle cells immediately after enzymatic dispersion (a) and of 10-d-old primary confluent cultures in supplemented Dulbecco's-modified Eagle's medium containing 10\% FCS $(b)$. The major actin spot is $\alpha$-actin in freshly isolated smooth muscle cells and $\beta$-actin in cultured confluent smooth muscle cells. Note also the increase of $\gamma$-actin in cultured cells. Note that in $b$, the vimentin spot $(V)$ is more pronounced than in $a$. Insert shows one-dimensional isoelectric focusing gels of the same preparations.

expression of rat and human smooth muscle cells during intimal thickening and atheroma formation provides a new proteinchemical marker that allows a better definition of the phenotype of these pathological cells.

It should be stressed that in regenerating, atheromatous, and cultured smooth muscle cells, the $\alpha$-isoform of actin never disappears completely, whereas mammalian nonmuscle cells, including fibroblasts, contain only the $\beta$ - and the $\gamma$-isoforms. This may represent a useful criterion in order to distinguish fibroblasts from smooth muscle cells in clinical conditions such as those characterized by the presence of myofibroblasts (25), where the distinction between these two cell types is frequently controversial.

It has been reported (9) that in rat aortic smooth muscle cells of intimal thickening following endothelial rèmoval, there is an increase of vimentin (Fig. 1) and a decrease of desmin content. It will be of interest to see whether there is a direct correlation between actin expression and intermediate filament remodeling under the same conditions. Cultured smooth muscle cells show changes in myosin expression according to the culture conditions $(5,29)$. Again it will be of interest to know whether changes of myosin expression in vitro (and possibly in vivo) are correlated with changes of actin expression under the same conditions. The switch of actin expression in smooth muscle cells cultured in the presence of $10 \%$ FCS compared with those cultured in the presence of PDS and $0.5 \%$ FCS supports the suggestion (for review see reference 5) that cultured smooth muscle cells represent a model of atheromatous smooth muscle cells. An established clonal smooth muscle cells line derived from the rat vena cava (30) has been reported to show a pattern of actin expression similar to that described above for cultured rat aortic smooth muscle cells. The presence of a switch in actin expression in actively replicating cultured smooth muscle cells compared with quiescent smooth muscle cells suggests that cell replication is one of the causes of this phenomenon. This may well apply to experimental rat intimal thickening and to human atheromatous plaques in which an increased proliferative activity of smooth muscle cells has been shown and/or suggested (31-34).

Recently, it has been reported that in cultured cells having a predominance of the $\alpha$-actin isoform, transformation with Rous sarcoma virus results in a decrease of this isoform with a concurrent increase of the $\beta$-isoform, similar to that reported here in cultured smooth muscle cells (35). Our experiments show that such switch between $\alpha$-and $\beta$-actin isoforms can take place in nontransformed cells under different culture conditions and suggest that it may be related to proliferative activity.

Further studies are needed in order to relate changes of actin expression to modifications of metabolic activities in atheromatous smooth muscle cells, compared with normal smooth muscle cells. In any event, the pattern of actin expression represents a new reliable protein-chemical marker for atheromatous smooth muscle cells and may contribute to a better understanding of their behaviour and biological reactions.

\section{Acknowledgments}

We thank Mrs. M Puype and Miss P. Patebex for excellent technical help.

This work was in part supported by the Swiss National Science Foundation, grant 3.178-0.82 and the Volkswagen Foundation.

\section{References}

1. Ross, R., and J. A. Glomset. 1976. The pathogenesis of atherosclerosis (First of two parts). N. Engl. J. Med. 295:369-377.

2. Ross, R., and J. A. Glomset. 1976. The pathogenesis of atherosclerosis (Second of two parts). N. Engl. J. Med. 295:420-425.

3. Haust, M. D. 1974. Reaction patterns of intimal mesenchyme to injury and repair in atherosclerosis. Adv. Exp. Med. Biol. 43:35-57.

4. Benditt, E. P., and A. M. Gown. 1980. Atheroma: the artery wall and the environment. Int. Rev. Exp. Pathol. 21:55-118. 
5. Chamley-Campbell, J., G. R. Campbell, and R. Ross. 1979. The smooth muscle cell in culture. Physiol. Rev. 59:1-61.

6. Baumgartner, H. R., and A. Studer. 1966. Folgen des Gefässkatheterismus am hypercholesterinaemischen Kaninchen. Pathol. Microbiol. 29:393-405.

7. Vandekerckhove, J., and K. Weber. 1978. At least six different actins are expressed in a higher mammal: an analysis based on the amino acid sequence of the amino-terminal tryptic peptide. J. Mol. Biol. 126:783-802.

8. Vandekerckhove, J., and K. Weber. 1979. The complete amino acid sequence of actins from bovine aorta, bovine heart, bovine fast skeletal muscle, and rabbit slow skeletal muscle. A protein-chemical analysis of muscle actin differentiation. Differentiation. 14:123-133.

9. Gabbiani, G., E. Rungger-Brändle, C. De Chastonay, and W. W. Franke. 1982. Vimentin-containing smooth muscle cells in aortic intimal thickening after endothelial injury. Lab. Invest. 47:265-269.

10. Gunther, S., R. W. Alexander, W. J. Atkinson, and M. A. Gimbrone. 1982. Functional angiotensin II receptors in cultured vascular smooth muscle cells. J. Cell Biol. 92:289-298.

11. Travo, P., G. Barrett, and G. Burnstock. 1980. Differences in proliferation of primary cultures of vascular smooth muscle cells taken from male and female rats. Blood Vessels. 17:110-116.

12. Ives, H. E., G. S. Schultz, R. E. Galardy, and J. D. Jamieson. 1978. Preparation of fractional smooth muscle cells from the rabbit aorta. J. Exp. Med. 148:1400-1413.

13. Vogel, A., E. Raines, B. Kariya, M.-J. Rivest, and R. Ross. 1978. Coordinate control of $3 \mathrm{~T} 3$ cell proliferation by platelet-derived growth factor and plasma components. Proc. Natl. Acad. Sci. USA. 75:28102814.

14. Low, R. B., C. Chaponnier, and G. Gabbiani. 1981. Organization of actin in epithelial cells during regenerative and neoplastic conditions: correlation of morphologic, immunofluorescent, and biochemical findings. Lab. Invest. 44:359-367.

15. Laemmli, U. K. 1970. Cleavage of structural proteins during the assembly of the head of bacteriophage T4. Nature (Lond.). 227:680685 .

16. Bradford, M. M. 1976. A rapid and sensitive method for the quantitation of microgram quantities of protein utilizing the principle of protein-dye binding. Anal. Biochem. 72:248-254.

17. O'Farrell, P. H. 1975. High resolution two-dimensional electrophoresis of proteins. J. Biol. Chem. 250:4007-4021.

18. Kelly, P. T., and C. W. Cotman. 1978. Synaptic proteins. Characterization of tubulin and actin and identification of a distinct postsynaptic density polypeptide. J. Cell Biol. 79:173-183.

19. Vandekerckhove, J., and K. Weber. 1981. Actin typing on total cellular extracts. A highly sensitive protein-chemical procedure able to distinguish different actins. Eur. J. Biochem. 113:595-603.

20. Robbins, S. L., and R. S. Cotran. 1979. Pathologic Basis of Disease. W. B. Saunders Co., Philadelphia. 601-603.
21. Small, D. M., and G. G. Shipley. 1974. Physical-chemical basis of lipid deposition in atherosclerosis. Science (Wash. DC). 185:222229.

22. Adeistein, R. S., S. P. Scordilis, and J. A. Trotter. 1979. The cytoskeleton and cell movement: general considerations. Methods Achiev. Exp. Pathol. 8:1-41.

23. Moll, R., W. W. Franke, D. L. Schiller, B. Geiger, and R. Krepler. 1982. The catalog of human cytokeratins: patterns of expression in normal epithelia, tumors, and cultured cells. Cell. 31:11-24.

24. Osborn, M., and K. Weber. 1182. Intermediate filaments: celltype-specific markers in differentiation and pathology. Cell. 31:303-306.

25. Rungger-Brändle, E., and G. Gabbiani. 1983. The role of cytoskeletal and cytocontractile elements in pathological processes. $\mathrm{Am}$. J. Pathol. 110:359-392.

26. Osborn, M., and K. Weber. 1983. Tumor diagnosis by intermediate filament typing: a novel tool for surgical pathology. Lab. Invest. 48:372-394.

27. Parker, F., and G. F. Odland. 1966. A light microscopic histochemical and electron microscopic study of experimental atherosclerosis in rabbit coronary artery and a comparison with rabbit aorta atherosclerosis. Am. J. Pathol. 48:451-481.

28. Imai, H., K. J. Lee, S. K. Lee, K. T. Lee, R. M. O'Neal, and W. A. Thomas. 1970. Ultrastructural features of aortic cells in mitosis in control and cholesterol-fed swine. Lab. Invest. 23:401-415.

29. Larson, D. M., K. Fujiwara, R. W. Alexander, and M. A. Gimbrone. 1982. Myosin in cultured vascular smooth muscle cells: immunochemical examination of altered antigenic expression. J. Cell Biol. 95:292a. (Abstr.)

30. Franke, W. W., E. Schmid, J. Vandekerckhove, and K. Weber. 1980. A permanently proliferating rat vascular smooth muscle cell with maintained expression of smooth muscle characteristics, including actin of the vascular smooth muscle type. J. Cell Biol. 87:594-600.

31. Hassler, O. 1970. The origin of the cells constituting arterial intima thickening. An experimental autoradiographic study with the use of $\mathrm{H}^{3}$-thymidine. Lab. Invest. 22:286-293.

32. Burns, E. R., T. H. Spaet, and M. B. Stemerman. 1978. Response of the arterial wall to endothelial removal: an autoradiographic study. Proc. Soc. Exp. Biol. Med. 159:473-477.

33. Goldberg, I. D., M. B. Stemerman, B. J. Ransil, and R. L. Fuhro. 1980. In vivo aortic muscle cell growth kinetics. Differences between thoracic and abdominal segments after intimal injury in the rabbit. Circ. Res. 47:182-189.

34. Orekhov, A. N., V. A. Kosykh, V. S. Repin, and V. N. Smirnov. 1983. Cell proliferation in normal and atherosclerotic human aorta. I. Flow cytofluorometric determination of cellular deoxyribonucleic acid content. Lab. Invest. 48:395-398.

35. Witt, D. P., D. J. Brown, and J. A. Gordon. 1983. Transformation-sensitive isoactin in passaged chick embryo fibroblasts transformed by Rous sarcoma virus. J. Cell Biol. 96:1766-1771. 